\title{
Sistem Informasi Rawat Inap Pasien di Puskesmas Paguyaman
}

\author{
Fajar Hermanto ${ }^{\left.{ }^{*}\right)}$ \\ Frangky Tupamahu ${ }^{2 *}$ \\ Program Studi Teknik Informatika, Politeknik Gorontalo \\ email : fajarhermanto@poligon.ac.id \\ email : frangkytupamahu@ poligon.ac.id
}

\begin{abstract}
ABSTRAK- Tugas akhir dengan judul Sistem Informasi Rawat Inap pada Puskesmas Paguyaman dengan permasalahan yang ada dalam pengolahan data administrasi rawat inap yang masih manual, maupun penyimpanan data yang belum terstruktur masih tersimpan dalam arsip yang terpisah-pisah, serta lamanya dalam pencarian data, perhitungan biaya maupun pembuatan laporan-laporan. Dengan adanya masalah tersebut, penulis mencoba membangun sistem yang mampu mengatasi permasalahan yang ada dalam pengolahan data Administrasi. Analisa yang dilakukan dengan studi lapangan yang meliputi interview atau tanya jawab langsung dengan pihak Puskesmas. Studi kepustakaan juga dilakukan dengan cara membaca dan mempelajari bukubuku literatur yang berhubungan dengan sistem informasi, maupun pencarian melalui internet. Perancangan sistem dan pembuatan aplikasi rawat inap dengan menggunakan aplikasi Netbeans 7.2 sebagai programnya, MySQL sebagai database server, dan Jasper Report untuk mencetak laporannya. Dari hasil analisis sistem dan penelitian bahwa Puskesmas Paguyaman sangat memerlukan Sistem Informasi Rawat Inap yang cepat dan akurat, sehingga dapat mengurangi kesalahan-kesalahan yang ada di Puskesmas Paguyaman. Dan dapat meningkatkan pelayanan kepada masyarakat, khususnya pada pasien rawat inap.
\end{abstract}

Kata kunci : Sistem Informasi, Rawat Inap, MYSQL, Netbeans 7.2 .

\section{PENDAHULUAN}

Pada jaman sekarang Teknologi informasi merupakan salah satu teknologi yang sedang berkembang pesat. Contohnya penggunaan komputer sebagai salah satu sarana penunjang dalam sistem informasi dapat memberikan hasil yang lebih untuk keluaran sebuah sistem, tentunya bila sistem di dalamnya telah berjalan dengan baik. Pengaruh kemajuan teknologi informasi berdampak pula pada Puskesmas yang bertujuan untuk meningkatkan pelayanan kesehatan masyarakat.

Puskesmas adalah salah satu intitusi pelayanan umum yang membutuhkan keberadaan suatu sistem informasi yang akurat, serta cukup memadai untuk meningkatkan pelayanan kesehatan masyarakat. Dengan ruang lingkup pelayanan yang luas banyak permasalahan yang terjadi dalam proses pelayanan di puskesmas.

\author{
Desi Djafar ${ }^{3 *}$ \\ Program Studi Teknik Informatika, Politeknik Gorontalo \\ email : desidjafar@gmail.com
}

Puskesmas (Pusat Kesehatan Masyarakat) merupakan organisasi fungisional yang menyelenggarakan upaya kesehatan yang bersifat menyeluruh, terpadu , merata, dapat diterima dan terjangkau oleh masyarakat, dengan peran serta aktif masyarakat dan menggunakan hasil pengembangan ilmu pengetahuan yang tepat dan berguna, dengan biaya yang dapat dipikul oleh pemerintah dan masyarakat. Upaya kesehatan tersebut diselenggarakan dengan menitik-beratkan kepada pelayanan untuk masyarakat luas guna mencapai derajat kesehatan yang optimal, tanpa mengabaikan mutu pelayanan kepada perorangan.

Kemajuan perkembangan puskesmas, baik dari aspek administratif atau teknologi, maka proses pelayanan kesehatan dapat berlangsung secara efektif dan efisien. Masalah yang terjadi pada puskesmas paguyaman adalah pelayanan pasien yang masih lambat. Proses pengolahan data masih dilakukan secara manual yaitu semua data pasien rawat inap masih dicatat di dalam buku album yang besar. Sehingga untuk mewujudkam hal tersebut serta mengembangkan mutu puskesmas Paguyaman dibutuhkan beberapa fasilitas pendukung yang dapat meningkatkan pelayanan serta memberikan kemudahan terhadap pasien dan memberikan informasi tentang rawat inap, seperti dokter yang bertugas, kamar pasien, obat-obatan, pelayanan pasien yang ada, sampai dengan pembayaran. Maka dari itu diperlukannya suatu aplikasi yang dapat memberikan informasi dan mengelola aplikasi tersebut.

Melihat dari situasi tersebut sudah sangat tepat jika di puskesmas paguyaman menggunakan sisi kemajuan komputer yang lebih mudah dalam membantu pelayanan terhadap pasien rawat inap dan pengelolaan data pasien yang menggunakan program komputer, salah satunya dengan aplikasi Netbeans.

Berdasarkan latar belakang diatas, maka penulis berencana membuat aplikasi yang akan lebih membantu dan mempermudah petugas dalam pelayanan kesehatan masyarakat dan pengolahan data pasien rawat inap yaitu "Sistem Informasi Rawat Inap Pasien di Puskesmas Paguyaman".

\section{METODE PENELITIAN}

Pada bagian ini menjelaskan mengenai gambaran umum pada Sistem Informasi Rawat Inap Pasien di Puskesmas Paguyaman. 


\subsection{Analisis Data}

Penulis mengumpulkan data dengan cara melakukan interview atau wawancara dengan pihak penanggung jawab atau petugas yang bertugas di bagian rawat inap.

\subsubsection{Bagan Alir Analisis yang Berjalan}

Analisis system bertujuan untuk mengetahui lebih jelas cara kerja system yang berjalan dan masalah yang dihadapi system itu sendiri. Analisis system ini merupakan landasan usulan perancangan sistem yang akan diajukan untuk merubah system yang sekarang menjadi system yang lebih baik.

Langkah awal yang dilakukan dalam pembuatan perancangan sistem informasi yaitu terlebih dahulu menganalisis sistem pengolahan data yang diperlukan dalam sistem informaasi ini.

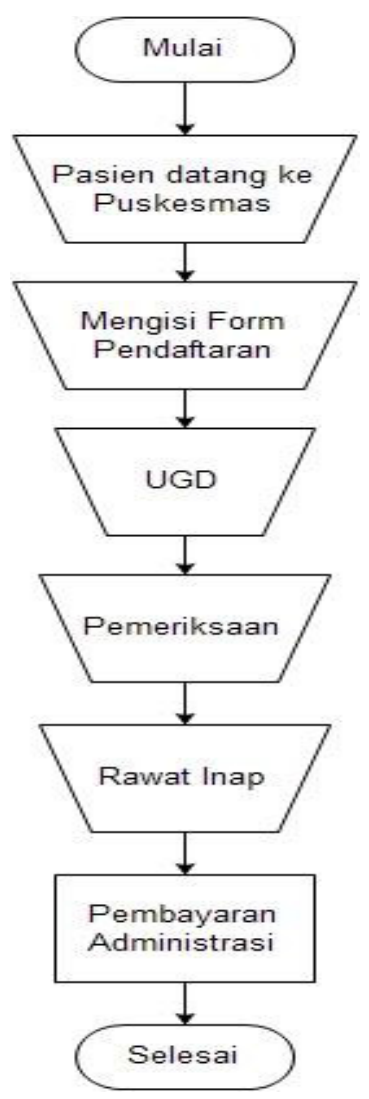

Gambar 2.1 Bagan Alir Analisis Sistem Yang Berjalan

Analisis data bertujuan menganalisa sistem yang ada agar dapat dilihat kekurangan dari sistem itu sendiri, hal ini dilakukan untuk memperbaharui sistem yang ada. Adapun

sistem yang berjalan pada sistem informasi rawat inap pasien di puskesmas di atas terlihat pada gambar 2.1 diatas.

\subsubsection{Bagan Alir Analisis Sistem yang diusulkan}

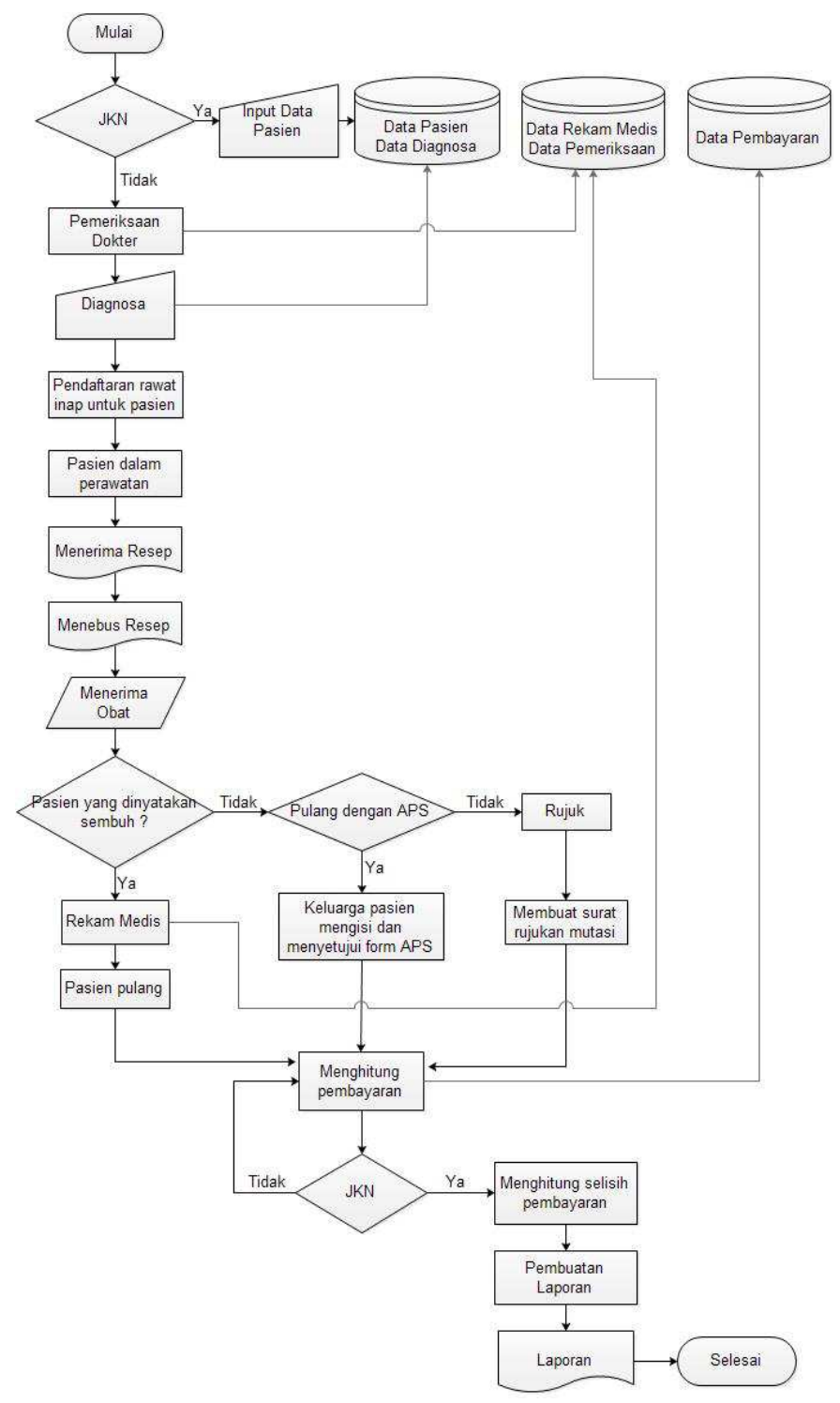

Gambar 2.2. Bagan Alir Sistem yang diusulkan

\subsubsection{Diagram Konteks yang diusulkan}

Setelah melakukan analisis bagan alir yang di usulkan, sistem yang pengolahanya masih seacara manual, maka pada sistem ini semua dilakukan secara terkomputerisasi dalam satu aplikasi lebih menghemat waktu, cepat, dan akurat. Aplikasi yang dapat mengolah serta memberikan kemudahan kepada setiap penggunaanya. Sehingga pengolahan data dan informasi yang cepat, tepat, jelas dan lebih akurat akan terpenuhi. 


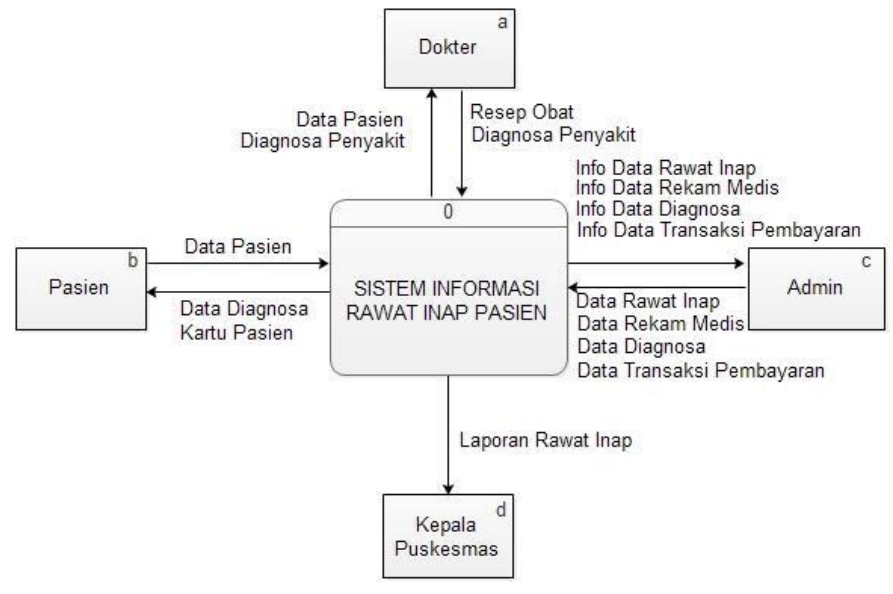

Gambar 2.3 Diagram Konteks yang diusulkan

\subsubsection{DAD (Diagram Arus Data)}

\section{DAD Level 0}

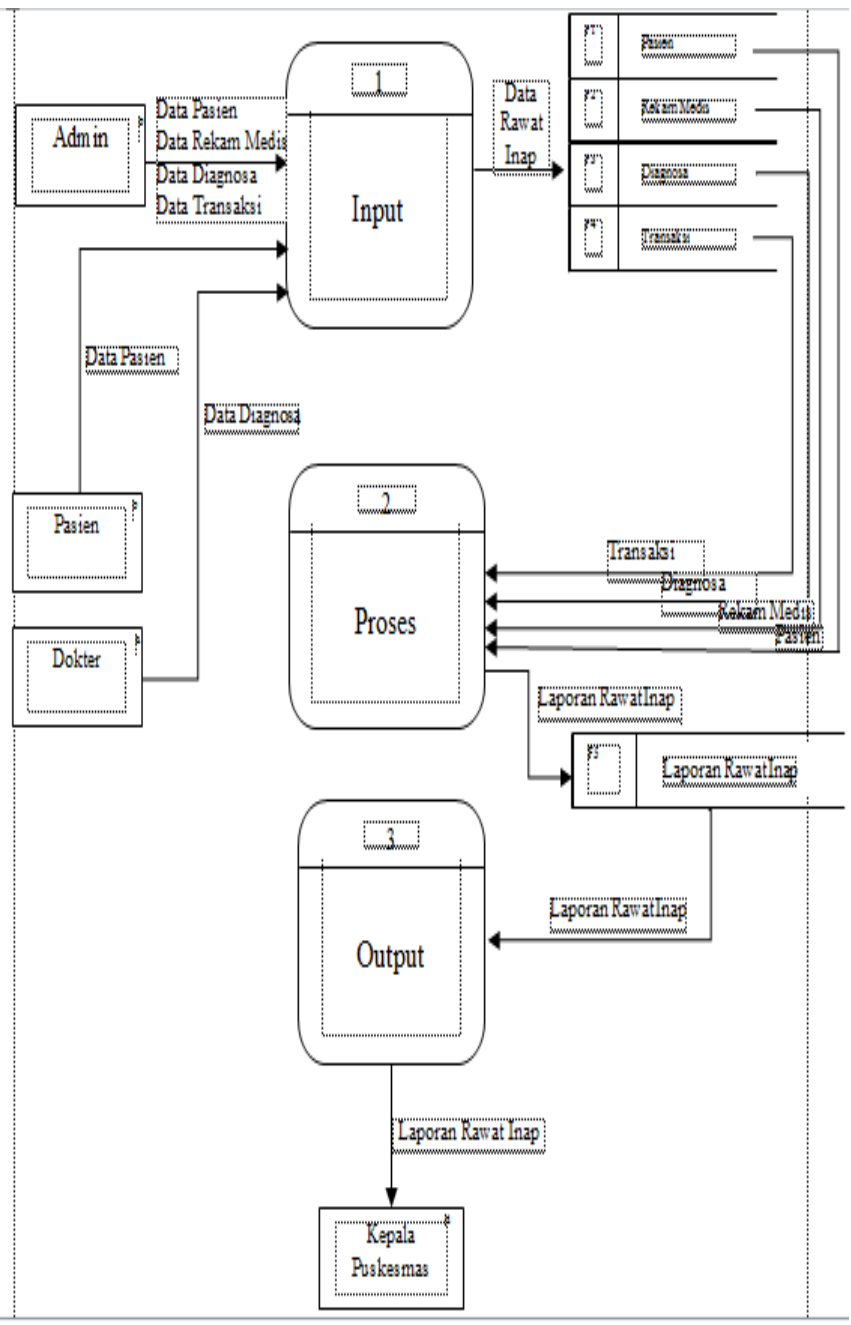

Gambar 2.4. DAD Level 0
- DAD Level 1

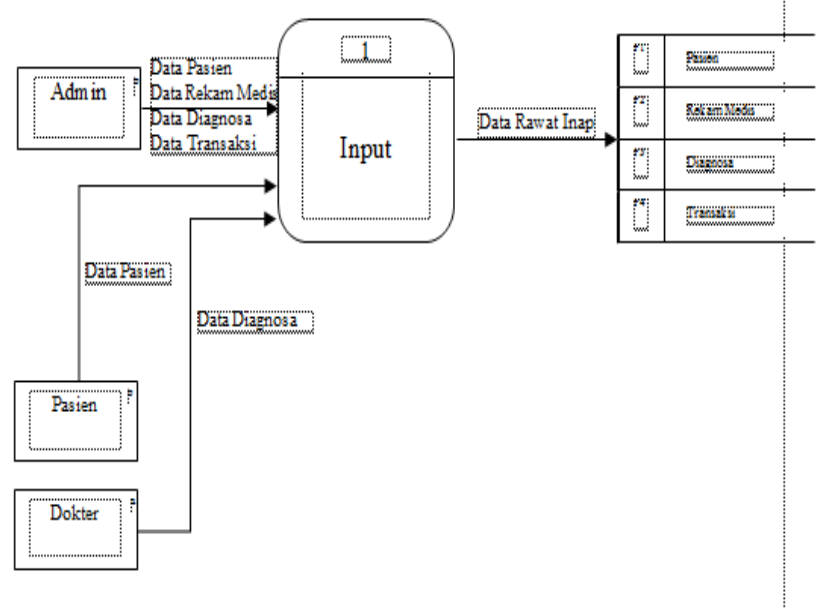

Gambar 2.5. DAD Level 1

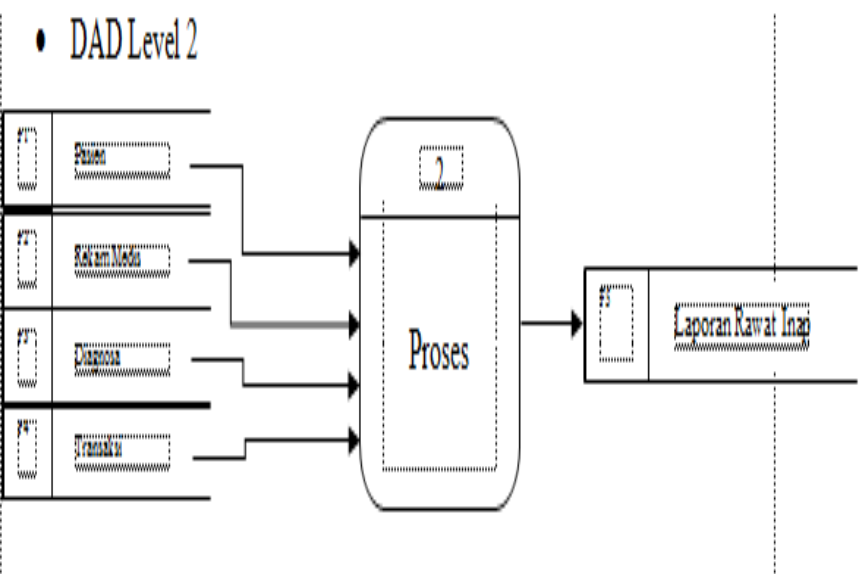

Gambar 2.6. DAD Level 2

- DAD Level 3

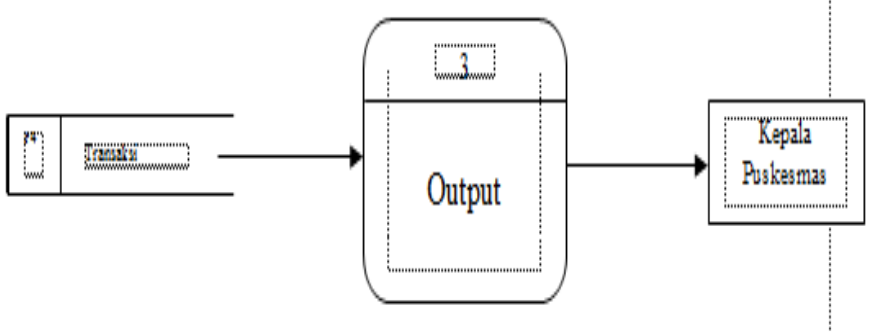

Gambar 2.7. DAD Level 3 


\subsection{Relasi}

\section{Tabel 2.1 Relasi}

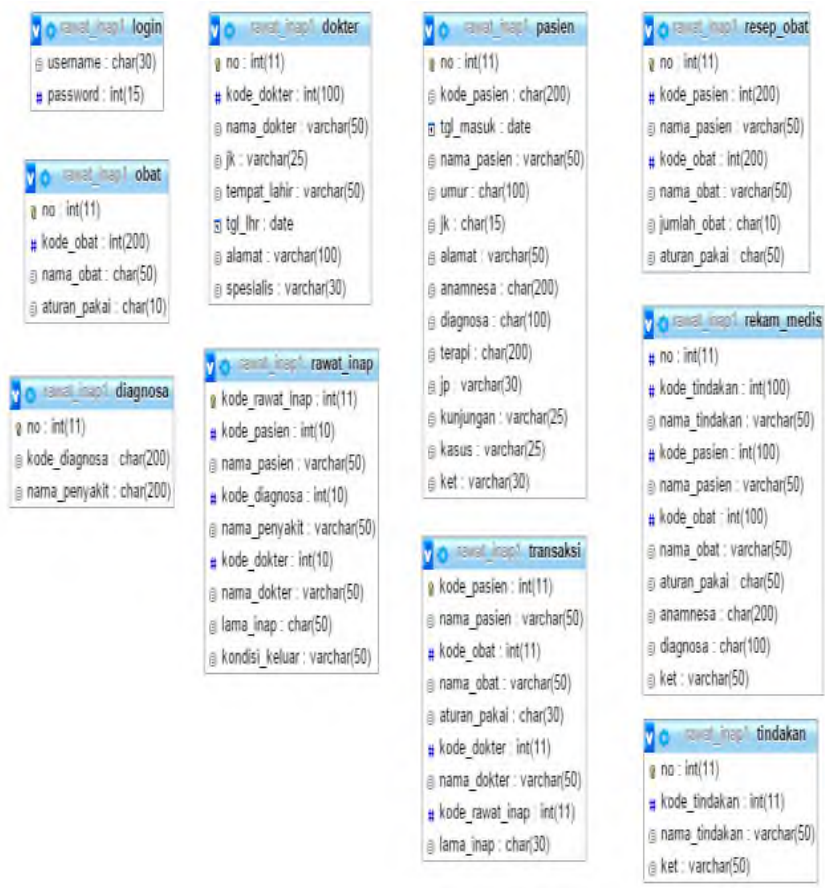

\section{HASIL DAN PEMBAHASAN}

\subsection{Hasil}

\subsubsection{Form Login Administrator}

Sebelum masuk ke dalam aplikasi untuk melakukan aktifitas transaksi dan sebagainya seorang administrator maupun user harus melakukan proses login terlebih dahulu dengan memasukkan username dan password. Berikut ini tampilan login Administrator seperti pada gambar 3.1.

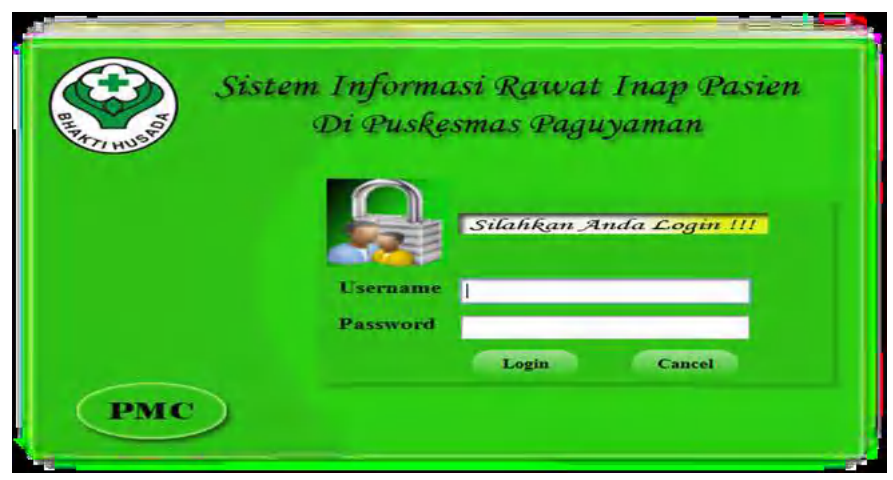

Gambar 3.1 Tampilan Login Administrator

\subsubsection{Tampilan Menu untuk Administrator}

Hak administrator adalah dapat menambahkan user baru serta melihat laporan transaksi. Setelah melakukan proses login, berikut ini tampilan menu untuk administrator seperti pada gambar 3.2.

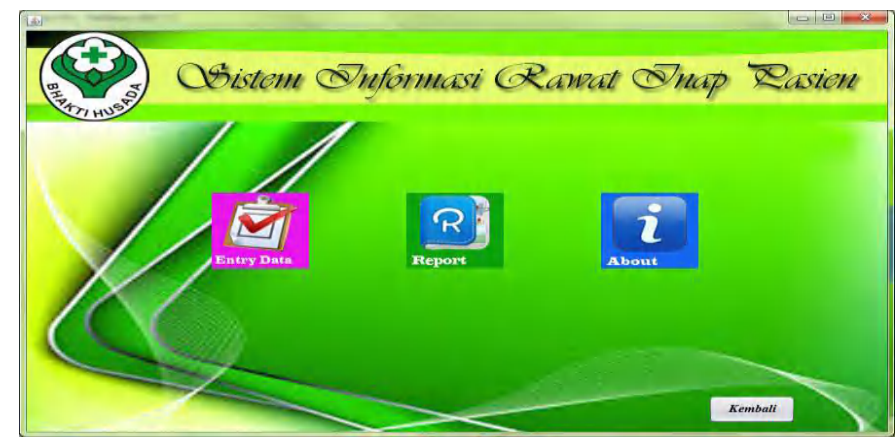

Gambar 3.2 Tampilan awal Administrator

\subsubsection{Tampilan Menu Entry Data}

Tampilan menu Entry Data memiliki 9 button yaitu Entry Data Pasien, Entry Data Dokter, Entry Data obat, Entry Data Diagnosa, Entry Data Resep Obat, Entry Data Tindakan, Entry Data Rekam Medis, Entry Data Rawat Inap, Entry Data Transaksi. Tampilannya seperti pada gambar 3.3.

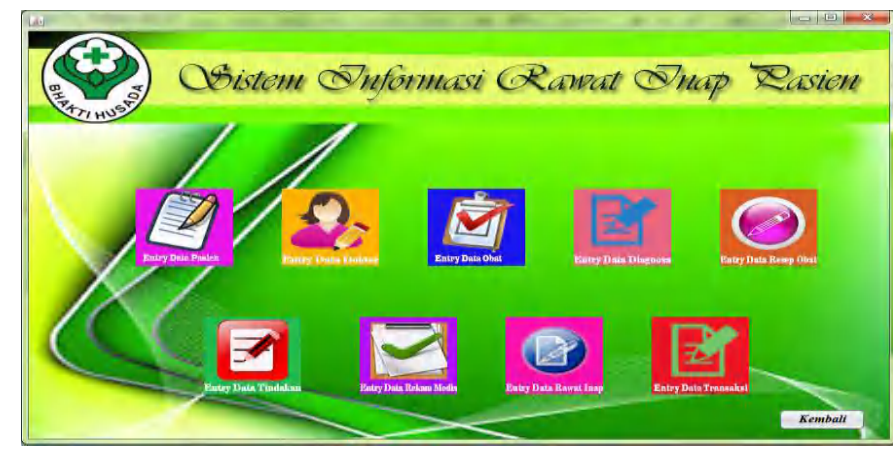

Gambar 3.3 Tampilan Menu Entry Data

\subsubsection{Laporan}

Pada menu laporan terdapat 3 pilihan laporan, yaitu Laporan Data Pasien, Laporan Data Rekam Medis dan Laporan Data Transaksi. Seperti pada gambar 3.4.

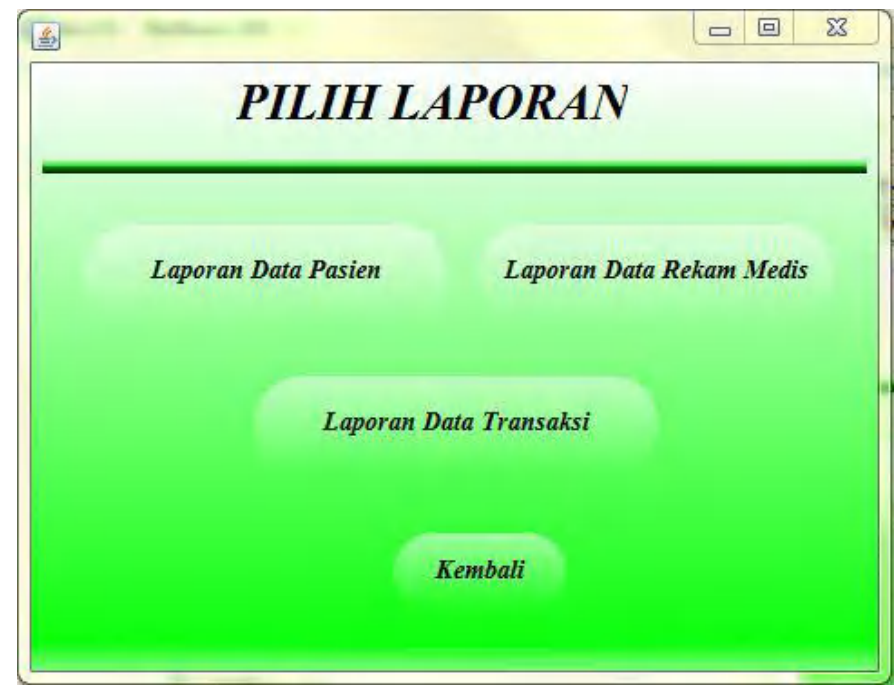

Gambar 3.4 Tampilan Menu Laporan 


\subsubsection{Laporan Data Pasien}

Menu ini menampilkan data pasien yang tersimpan di dalam database. Data tersebut dapat di simpan dan di cetak. Seperti pada gambar 3.5.

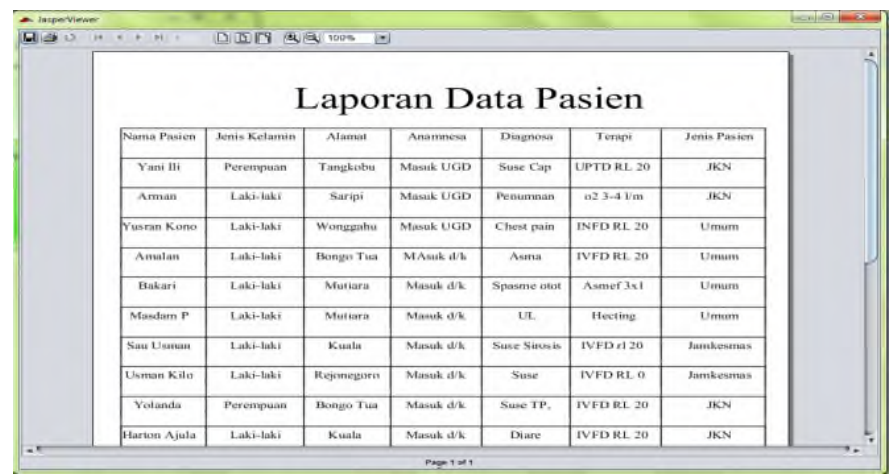

Gambar 3.5 Tampilan Laporan Data Pasien

\subsubsection{Menu Entry Data Pasien}

Menu ini berfungsi untuk menambahkan daftar Pasien seperti pada gambar 3.6.

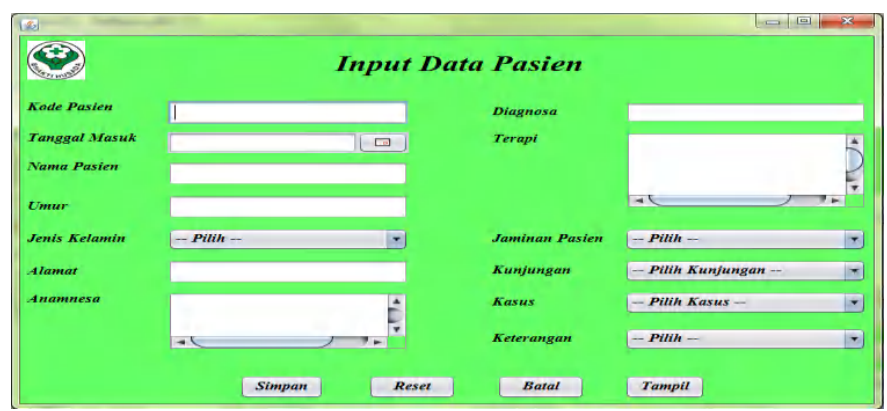

Gambar 3.6 Entry Data Pasien

\subsubsection{Data pasien}

Меnu data Pasien merupakan menu yang menampilkan data pasien,. Dimana data-data tersebut dapat kita ubah dan dapat kita hapus. Berikut Deskripsi data Pasien seperti pada gambar 3.7.

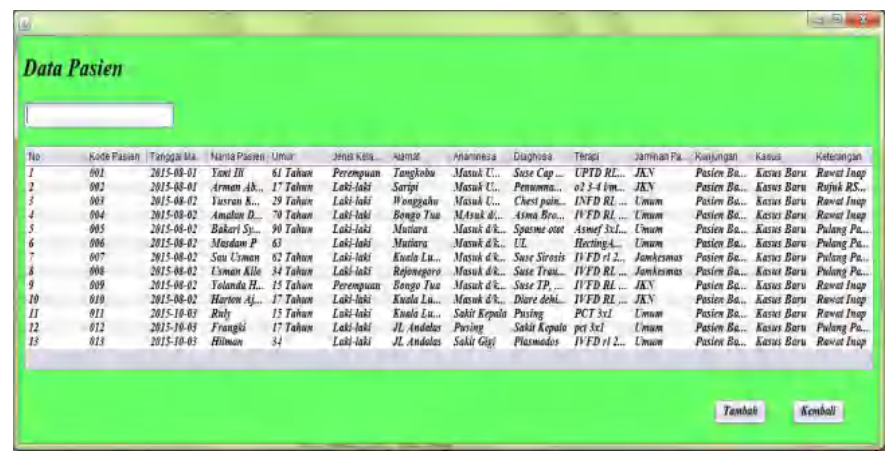

Gambar 3.7 Data Pasien

\subsubsection{Menu Tentang}

Menu ini berisi tentang informasi pembuat aplikasi seperti pada gambar 3.8.

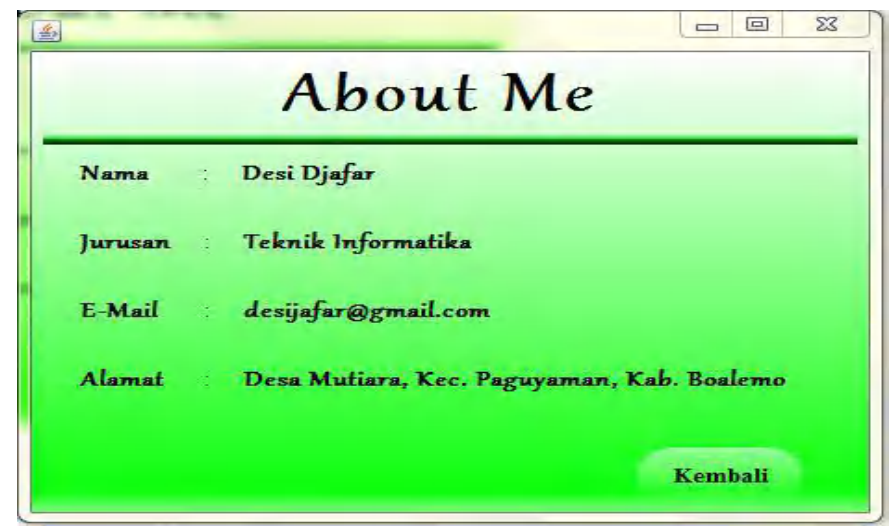

Gambar 3.8 Tampilan Tentang

\section{KESIMPULAN}

\subsection{Kesimpulan}

Berdasarkan hasil penelitian yang penulis lakukan di Puskesmas Paguyaman sistem yang berjalan selama ini menghasilkan kesimpulan yaitu sistem yang berjalan selama ini belum mengasilkan informasi yang optimal mengenai pendataan, transaksi pembayaran dan proses pembuatan laporan, sehingga diperlukan sebuah sistem yang dapat memberikan informasi yang lebih optimal, serta mempermudah dan mempercepat petugas puskesmas.

Dengan adanya Sistem Informasi Rawat Inap Pasien mampu mengetahui dan mengolah data pasien, data petugas jaga, data obat, data diagnosa dan data transaksi pembayaran serta pembuatan laporan yang ada pada puskesmas paguyaman dapat mengatasi permasalahan yang ada dalam pengolahan data adaministrasi rawat inap untuk meningkatkan pelayanan masayarakat yang efektif dan efisien.

\subsection{Saran}

Dari kesimpulan yang telah disebutkan diatas, penulis memberikan beberapa saran untuk pengembangan lebih lanjut dari Sistem Informasi Rawat Inap Pasien di Puskesmas Paguyaman sebagai berikut :

1. Untuk menunjang keefektivitasan operasional sistem yang baik dan lancar maka diperlukan suatu peralatan pendukung (PC/laptop) yang baik dan menunjang, dalam arti harus bisa menjalankan sistem operasi dari software Sistem Informasi Rawat Inap yang telah dirancang.

2. Diharapkan sistem ini dapat diterapkan pada Puskesmas Paguyaman.

\section{DAFTAR PUSTAKA}

[1] Ladjamudin, Al-Bahra Bin, 2013, Analisis Dan Desain Sistem Informasi ,Graha Ilmu. KBBI, 2013.,” Puskesmas “.

[2] Kadir, Abdul, 2014, Buku Pertama Belajar Pemrograman Java untuk Pemula. 